\title{
IDENTIFIKASI KESULITAN SISWA DALAM MENYELESAIKAN SOAL ARITMATIKA SOSIAL
}

\author{
Oki Ratna Dila1, Luvy Sylviana Zanthy² \\ 1,2 IKIP Siliwangi Bandung, Jl. Terusan Jenderal Sudirman, Cimahi, Indonesia \\ Email: oki.ratna12@gmail.com
}

\begin{abstract}
Social arithmetic is one of the material that is important for students to learn because it relates to the application of mathematics in daily life, for example: calculating the purchase price and sales price, profit and loss, interest, discount, Tax, Gross, Tara, and net. But in fact students are still struggling to learn the material. Therefore, research needs to be done to identify students ' difficulties in solving social arithmetic problems. The purpose of this research is to find out the difficulties experienced by the students and the causes in solving social arithmetic problems. This method of research is a qualitative descriptive. The data collection tools used in the form of instruments, with the data analysis procedures used are data gathering, data processing, and data presentation, as well as withdrawal of conclusions. The results of this study indicate that there are three types of difficulties: (1) difficulty in language aspects, for example students are difficult to understand or interpret the problem and can not retell the intent to use the language itself; (2) The difficulties of the prerequisite, for example, students do not write what is known and asked, and do not understand the concept so it is difficult to determine the formula used; and (3) The difficulties of applied aspects, for example students can not do the calculations appropriately, and give no conclusion to the answer. This difficulty is due to students not yet familiar with social arithmetic material. In conclusion, students are still experiencing difficulties in solving social arithmetic problems.
\end{abstract}

Keywords: Difficulty analysis, social arithmetic, problem solving

\begin{abstract}
ABSTRAK
Aritmatika sosial merupakan salah satu materi yang penting untuk dipelajari siswa karena berkaitan dengan penerapan matematika dalam kehidupan sehari-hari, misalnya: menghitung harga pembelian dan harga penjualan, keuntungan dan kerugian, bunga, diskon, pajak, bruto, tara, dan neto. Tetapi pada kenyataannya siswa masih kesulitan dalam mempelajari materi tersebut. Oleh karena itu, perlu dilakukan penelitian untuk mengidentifikasi kesulitan siswa dalam menyelesaikan soal aritmatika sosial. Tujuan penelitian ini adalah untuk mengetahui kesulitan yang dialami siswa dan penyebabnya dalam menyelesaikan soal aritmatika sosial. Metode penelitian ini yaitu deskriptif yang bersifat kualitatif. Alat pengumpul data yang digunakan berupa instrumen soal, dengan prosedur analisis data yang digunakan yaitu pengumpulan data, pengolahan data, dan penyajian data, serta penarikan kesimpulan. Hasil penelitian ini menunjukkan ada tiga jenis kesulitan yaitu: (1) kesulitan aspek bahasa, misalnya siswa sulit memahami atau menafsirkan soal dan tidak dapat menceritakan kembali maksud soal menggunakan bahasa sendiri; (2) kesulitan aspek prasyarat, misalnya siswa tidak menuliskan apa yang diketahui dan ditanyakan, serta kurang memahami konsep sehingga sulit menentukan rumus yang digunakan; dan (3) kesulitan aspek terapan, misalnya siswa tidak dapat melakukan perhitungan dengan tepat, dan tidak memberikan kesimpulan jawaban. Kesulitan ini disebabkan karena siswa belum paham dengan materi aritmatika sosial. Kesimpulannya yaitu siswa masih banyak mengalami kesulitan dalam menyelesaikan soal aritmatika sosial.
\end{abstract}

Kata kunci: Analisis kesulitan, aritmatika sosial, penyelesaian soal

Dikirim: 02 Desember 2019; Diterima: 15 Februari 2020; Dipublikasikan: 30 Maret 2020

Cara sitasi: Dila, O. R., \& Zanthy, L. S. (2020). Identifikasi kesulitan siswa dalam menyelesaikan soal aritmatika sosial. Teorema: Teori dan Riset Matematika, 5(1), 17-26. 


\section{PENDAHULUAN}

Matematika erat kaitannya dengan pendidikan terutama dalam perkembangan ilmu pengetahuan dan teknologi. Mengingat pentingnya matematika tersebut, maka matematika perlu dipahami dan dikuasai oleh semua lapisan masyarakat terutama di sekolah. Menurut Ruseffendi (Marina \& Suciati, 2019) mengemukakan bahwa matematika penting sebagai pembentuk sikap, sehingga guru harus mendorong siswa untuk dapat belajar dengan baik.

Pembelajaran merupakan suatu upaya dalam memperbaiki kualitas mutu pendidikan (Raharjo \& Sulaiman, 2017). Sejalan dengan ini, Doddington \& Hilton (Marina \& Suciati, 2019) mengemukakan bahwa pembelajaran akan berlangsung dengan baik jika ada timbal balik antara guru dan siswa. Oleh karena itu, siswa dituntut untuk aktif, kreatif, dan inovatif dalam menanggapi setiap pembelajaran yang diajarkan oleh guru sehingga materi yang disampaikan dapat diterima.

Menurut pendapat Turmudi (Nuraida, 2017), pembelajaran matematika yang disampaikan kepada siswa selama ini hanya secara informatif, sehingga kemampuan mengingatnya rendah. Siswa tidak dilibatkan dalam menemukan konsep, sehingga siswa mudah lupa dan bingung jika diberikan soal oleh guru. Kekurangpahaman siswa terhadap konsep matematika berasal dari beberapa faktor yang mempengaruhi, misalnya pembelajaran matematika perlu melibatkan siswa secara aktif, belajar bersama teman sebaya, dan menemukan sendiri, serta dapat menghubungkan dalam kehidupan sehari-hari.

Matematika merupakan salah satu mata pelajaran yang dianggap sulit di sekolah, karena untuk mempelajarinya memerlukan tingkat berpikir tinggi sehingga sebagian siswa mengatakan matematika adalah pelajaran yang sulit dan membosankan. Untuk meningkatkan kemampuan berpikir matematis tingkat tinggi, siswa perlu dibiasakan memecahkan masalah-masalah kontekstual nonrutin (Fatimah \& Zakiah, 2018). Hal ini dapat dilakukan salah satunya dengan memberikan soal cerita yang sesuai dengan materi yang sedang dipelajari.

Khasanah \& Sutaman (2015) mengemukakan bahwa ada 3 aspek dalam menyelesaikan soal cerita matematika, yaitu: (1) Aspek bahasa, merupakan kemampuan membaca yang digunakan untuk menafsirkan masalah, sedangkan menalar adalah untuk mengetahui maksud permasalahan yang diberikan. Sejalan dengan pendapat Laily (2014) bahwa pelajaran bahasa yang paling mendasar adalah membaca, dengan membaca harus menghasilkan pengertian sehingga pemahaman yang dimiliki siswa bukan kemampuan turun-temurun, tetapi hasil proses belajar mengajar yang dilakukan dengan tekun dan terlatih. (2) Aspek prasyarat, merupakan kemampuan mengubah model matematika dan menentukan strategi untuk menyelesaikan masalah. Erliani (Khasanah \& Sutaman, 2015) berpendapat bahwa soal cerita yang diberikan kepada siswa menggunakan bahasa yang sudah dikuasainya maka akan memudahkan siswa dalam mengubah ke model matematika. Kemudian Polya (Khasanah \& Sutaman, 2015) mengemukakan bahwa siswa dalam memecahkan masalah harus dapat menyelesaikan jawaban dengan menggunakan aturan-aturan rumus yang sudah dipelajarinya. (3) Aspek terapan, merupakan kemampuan siswa melakukan proses perhitungan yang tepat dengan menggunakan rumus.

Berdasarkan penelitian Lestari et.al, (2019) menyimpulkan bahwa siswa dalam menyelesaikan soal aritmatika sosial mengalami kesulitan konsep dan kesulitan verbal. Senada dengan pendapat White (2010) mengemukakan bahwa "process skills errors, the child identified an appropriate operation, or sequence of operations, but did not know the procedures necessary to carry out these operations accuractly", artinya kesalahan terjadi ketika siswa dapat menentukan operasi yang harus dilakukan, tetapi tidak dapat menuliskan prosedur operasi tersebut. Hal ini diperkuat dengan pendapat Zakiah (2017) bahwa kemampuan untuk menemukan strategi yang tepat merupakan kemampuan yang sangat penting dalam belajar matematika. Apabila siswa sudah memiliki kemampuan menemukan strategi pemecahan masalah, maka siswa akan mampu meminimalisir kesalahan yang dibuatnya.

Berdasarkan penelitian Khasanah \& Sutaman (2015) menyimpulkan bahwa kesulitan siswa dalam menyelesaikan soal matematika yaitu: (1) kesulitan aspek bahasa, misalnya siswa salah menafsirkan soal, memahami soal, dan mengidentifikasi maksud soal, serta menceritakan kembali soal dengan bahasa sendiri; (2) kesulitan aspek prasyarat, misalnya siswa tidak menuliskan apa yang diketahui dan ditanyakan, mengubah ke bentuk model matematika, dan tidak menguasai konsep 
sehingga sulit menentukan rumus; (3) kesulitan aspek terapan, misalnya tidak bisa menggunakan rumus dengan tepat, hal ini berakibat kurangnya ketelitian siswa.

Menurut penelitian Lestari et.al (2019) menyimpulkan bahwa kesulitan belajar siswa baik dalam pemahaman konsep maupun verbal dipengaruhi oleh rendahnya kemampuan komunikasi siswa. Walaupun tidak semua siswa mengalami kesulitan dalam memahami konsep dalam pembelajaran matematika. Sedangkan, menurut penelitian Sari (2017) menyimpulkan bahwa kesulitan terjadi karena kurangnya sarana dan prasarana pembelajaran, kurang memahami konsep matematika dengan baik yang telah dipelajari sebelumnya, tidak paham dengan rumus yang telah digunakan, tidak dapat mengaitkan konsep matematika yang sudah dipelajari dengan konsep yang akan dipelajari, siswa sering lupa dengan konsep matematika, siswa belajar dari contoh soal seharusnya dari kebiasaan belajar, kurangnya motivasi siswa dalam belajar, siswa kurang sadar akan manfaat mempelajari konsep matematika, serta tidak megaplikasikan pemahamannya secara langsung dalam kehidupan sehari-hari.

Aritmatika sosial merupakan salah satu materi yang penting untuk dipelajari oleh siswa karena berkaitan dengan harga penjualan, harga pembelian, keuntungan, kerugian, bunga, diskon, pajak, bruto, tara, dan neto sehingga akan berguna pada saat menyelesaikan masalah tersebut di masa yang akan datang. Walaupun materi itu penting untuk dipelajari, tetapi pada kenyataannya siswa mengalami kesulitan dalam menyelesaikan masalah tersebut, sehingga penting untuk dilakukannya penelitian.

Berdasarkan hasil penelitian yang dilakukan Evijayanti \& Khotimah (2018) di Surakarta menyimpulkan bahwa jenis kesulitan yang dialami siswa dalam menyelesaikan soal cerita aritmatika sosial digolongkan menjadi tiga, yaitu: (1) kesulitan dalam memahami soal; (2) kesulitan dalam mentransformasikan soal; dan (3) kesulitan dalam proses penyelesaian. Penyebabnya adalah siswa malas membaca soal yang panjang, kesulitan dalam menafsirkan soal, minat belajar siswa kurang, siswa cenderung lebih menghafal daripada memahami konsep, siswa kurang latihan soal-soal, masih salah dalam melakukan perhitungan, motivasi belajar siswa rendah, pada saat pembelajaran di kelas kurang kondusif dan metode pembelajaran yang digunakan oleh guru adalah metode ceramah.

Selanjutnya, hasil penelitian yang dilakukan (Shalikhah, 2019) di Yogyakarta menyimpulkan bahwa kesulitan yang dihadapi siswa dalam menyelesaikan soal aritmatika sosial yaitu: kesulitan dalam melakukan algoritma penyelesaian soal dan kesulitan dalam memahami konsep yang saling berkaitan. Alternatif pemecahan masalah untuk mengatasi kesulitan siswa dalam menyelesaikan soal aritmatika sosial yaitu dapat diatasi dengan menerapkan metode role playing (bermain peran) dengan memanfaatkan kantin sekolah.

Kemudian, hasil penelitian yang dilakukan Fitri et.al (2017) di Karawang menyimpulkan bahwa siswa masih kurang mampu menyelesaikan soal cerita aritmatika sosial, yaitu: (1) siswa yang memiliki kemampuan tinggi mengalami kesulitan pada penyelesaian, memeriksa kembali proses dan hasil penyelesaian; (2) siswa yang memiliki kemampuan sedang mengalami kesulitan dalam merencanakan penyelesaian, melaksanakan rencana penyelesaian dan memeriksa kembali proses dan hasil penyelesaian; dan (3) siswa yang memiliki kemampuan rendah mengalami kesulitan dalam memahami masalah, merencanakan penyelesaian, melaksanakan rencana penyelesaian dan memeriksa kembali proses dan hasil penyelesaian. Penyebabnya adalah kesulitan itu timbul dari segi internal yaitu kecerdasan, minat, dan bakat. Sedangkan, dari segi eksternal yaitu lingkungan kelas.

Berdasarkan penelitian yang sudah dilakukan di beberapa kota dan pembahasannya yang berbeda, oleh karena itu peneliti tertarik untuk melakukan penelitian di kota Cimahi dengan penelitian yang sejenis, tetapi dengan pembahasan yang berbeda yaitu berdasarkan aspek bahasa, aspek prasyarat, dan aspek terapan.

\section{METODE PENELITIAN}

Subjek penelitian ini adalah salah satu SMP di Kota Cimahi, kelas VIII yang terdiri dari 40 siswa. Penelitian ini termasuk kedalam penelitian deskriptif kualitatif yang bertujuan untuk mengetahui kesulitankesulitan yang dialami siswa dan penyebabnya dalam menyelesaikan soal aritmatika sosial. Data pada penelitian ini berupa jawaban tertulis siswa dari instrumen tes yang memuat 5 butir soal. Instrumen ini 
dimodifikasi dari penelitian Andriani (2017) yang sudah diketahui kevalidan tiap butir soalnya. Teknik analisis yang digunakan terdiri atas: (1) pengumpulan data, dilakukan untuk memperoleh data yang relevan sehingga dapat digunakan secara tepat sesuai dengan tujuan penelitian; (2) reduksi data, dilakukan untuk mengelompokkan jenis kesulitan; (3) penyajian data, dilakukan untuk memudahkan dalam melaksanakan penarikan kesimpulan; dan (4) penarikan kesimpulan, yaitu menyimpulkan data yang diperoleh dari hasil tes sesuai dengan permasalahan dan tujuan penelitian.

\section{HASIL DAN PEMBAHASAN}

Penelitian dilaksanakan pada salah satu SMP di Kota Cimahi kelas VIII yang berjumlah 40 orang siswa. Kesalahan-kesalahan siswa yang dapat dideskripsikan dalam penelitian ini diantaranya: siswa belum mampu membaca dan memahami soal dengan tepat, siswa belum bisa menceritakan kembali soal dengan bahasa sendiri, siswa tidak menuliskan apa yang diketahui dan ditanyakan, siswa belum memahami konsep sehingga salah dalam menentukan rumus yang akan digunakan, masih salah dalam melakukan perhitungan, dan siswa tidak menarik kesimpulan dari hasil jawabannya. Berdasarkan kesalahan tersebut, maka perlu adanya identifikasi terhadap tiga aspek, yaitu (1) aspek bahasa; (2) aspek prasyarat; dan (3) aspek terapan. Aspek bahasa yaitu kemampuan membaca yang digunakan untuk menafsirkan masalah dan kemampuan menalar yaitu untuk mengetahui maksud permasalahan yang diberikan. Aspek prasyarat yaitu agar siswa dapat menentukan konsep dan rumus yang digunakan dengan tepat untuk menyelesaikan masalah. Aspek terapan yaitu berkaitan dengan aspek prasyarat, siswa diharapkan dapat melakukan perhitungan dengan benar dan dapat menarik kesimpulan dari hasil jawabannya tersebut. Berikut adalah data hasil tes terhadap kesulitan siswa disajikan ke dalam tabel.

Tabel 1.

Data kesulitan hasil jawaban siswa

\begin{tabular}{lcc}
\hline \multicolumn{1}{c}{ Aspek } & Jumlah & Persentase (\%) \\
\hline Aspek bahasa & 20 & 50 \\
Aspek prasyarat & 30 & 75 \\
Aspek terapan & 20 & 50 \\
\hline
\end{tabular}

Berdasarkan Tabel 1 menunjukkan bahwa: (1) siswa mengalami kesulitan pada aspek bahasa sebesar $50 \%$, kesulitan tersebut antara lain siswa sulit memahami atau menafsirkan soal dan tidak dapat menceritakan kembali maksud soal dengan menggunakan bahasanya sendiri; (2) siswa mengalami kesulitan pada aspek prasyarat sebesar $75 \%$, kesulitan tersebut adalah siswa tidak menuliskan apa yang diketahui dan ditanyakan, serta siswa kurang memahami konsep sehingga kesulitan menentukan rumus; (3) siswa mengalami kesulitan pada aspek terapan sebesar $50 \%$, kesulitan tersebut yaitu siswa dalam melakukan perhitungan kurang tepat, dan tidak membuat kesimpulan. Berdasarkan tabel tersebut dapat diketahui bahwa kesulitan terbesar siswa terlihat pada aspek prasyarat.

Setelah semua jawaban siswa dianalisis dan diperiksa, peneliti akan menganalisis salah satu hasil jawaban siswa dilihat dari jawaban soal sebagai berikut:

Permasalahan soal nomor 1 :

Jika harga $1 \mathrm{~kg}$ gula Rp. 5.500,00 dan harga $1 \mathrm{~kg}$ tepung terigu Rp. 4.700,00. Tentukan:

(a) persamaan dari $5 \mathrm{~kg}$ gula dan $3 \mathrm{~kg}$ tepung terigu.

(b) berapa harganya? 


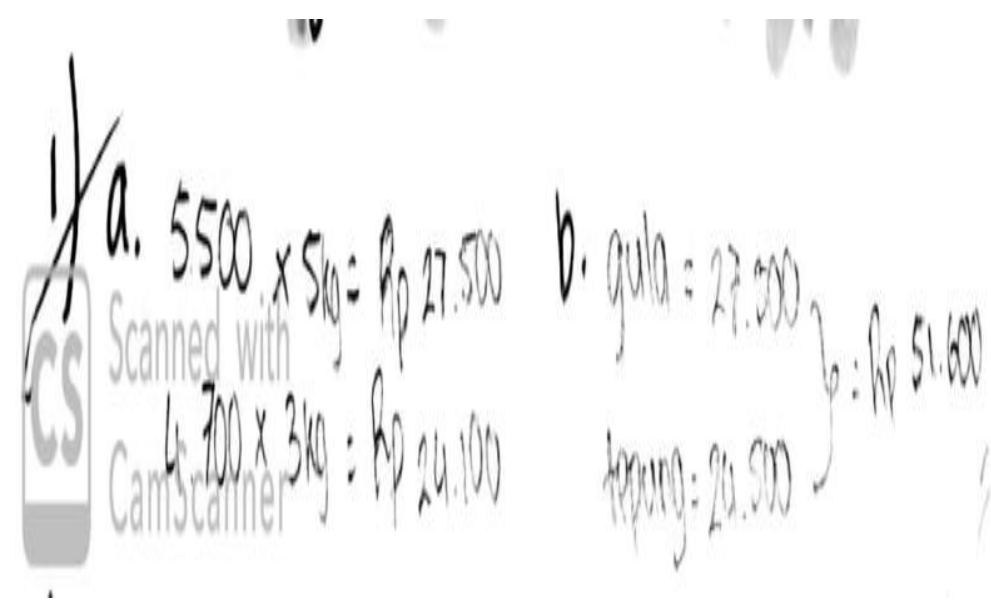

Gambar 1. Jawaban siswa pada soal nomor 1

Jawaban siswa pada Gambar 1 terlihat bahwa siswa mengalami kesulitan pada aspek bahasa, aspek prasyarat, dan aspek terapan. Pada aspek bahasa, siswa kesulitan dalam menafsirkan soal, sehingga jawaban salah. Seharusnya siswa membuat persamaannya terlebih dahulu dari $5 \mathrm{~kg}$ gula dan $3 \mathrm{~kg}$ tepung terigu, misalnya: $5 \mathrm{x}+3 \mathrm{y}$. Pada aspek prasyarat, seharusnya siswa menuliskan apa yang diketahui dan ditanyakan pada jawaban siswa tersebut, tetapi ternyata siswa tidak menuliskannya mungkin karena lupa atau tidak terbiasa. Berdasarkan soal seharusnya yang diketahui: harga $1 \mathrm{~kg}$ gula = Rp. 5.500,00; harga $1 \mathrm{~kg}$ tepung terigu = Rp. 4.700,00. Ditanyakan: (a) persamaan dari $5 \mathrm{~kg}$ gula dan $3 \mathrm{~kg}$ tepung terigu? (b) berapa harganya?. Siswa sulit menentukan rumus, seharusnya dari persamaan tersebut bisa dijadikan rumus untuk mencari berapa harganya. Pada aspek terapan, siswa dalam mengimplementasikan persamaan pada pertanyaan a ke pertanyaan $\mathrm{b}$ masih salah, sehingga dalam melakukan perhitungan tidak sesuai dengan jawaban yang diinginkan peneliti. Seharusnya pada pertanyaan (b) berapa harganya? jawaban siswa yaitu: $5 x+3 y=(5 x$ Rp. $5 \cdot 500,00)+(3 x$ Rp. $4 \cdot 700,00)=R p .27 \cdot 500,00+R p$. $14.100,00=$ Rp. $41.600,00$. Jawaban siswa pada Gambar 1 juga tidak membuat simpulan dari hasil perhitungannya, seharusnya dari hasil perhitungan tersebut dibuat kesimpulannya sesuai dengan soal yang ditanyakan, misal: jadi harga $5 \mathrm{~kg}$ gula $+3 \mathrm{~kg}$ tepung terigu $=\mathrm{Rp} 41.600,00$.

Permasalahan soal nomor 2:

Sebuah barang dibeli dengan harga Rp. 7.500,00 dan dijual dengan laba 25\%. Tentukan harga jual barang tersebut.

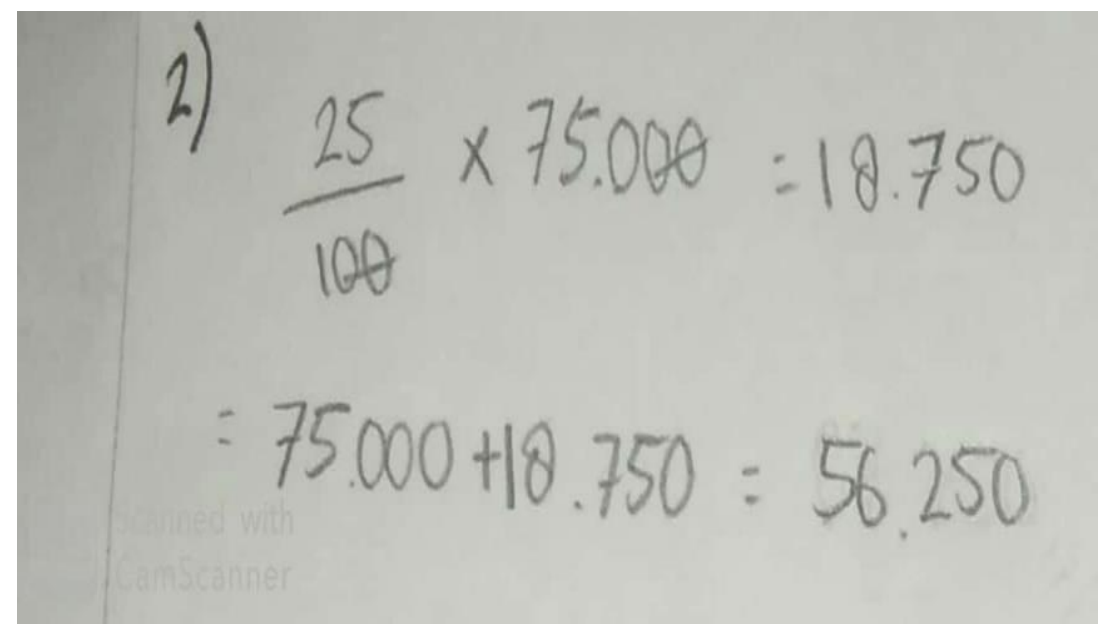

Gambar 2. Jawaban siswa pada soal nomor 2 
Jawaban siswa pada Gambar 2 menunjukkan bahwa siswa mengalami kesulitan dalam menyelesaikan soal tersebut yaitu: pada aspek bahasa, siswa kesulitan dalam menceritakan kembali soal tersebut dengan bahasanya sendiri misalnya: siswa tidak menuliskan apa yang sebenarnya akan dicari dari soal tersebut dengan kata-katanya sendiri. Seharusnya siswa menuliskan untuk menentukan harga jual barang, langkah pertama mencari laba, kemudian langkah kedua menentukan harga jual. Selanjutnya aspek prasyarat, sama dengan jawaban sebelumnya yaitu siswa tidak menuliskan apa yang diketahui dan ditanyakan, seharusnya tetap dituliskan walaupun tidak ada dalam pertanyaan, misalnya: diketahui harga beli barang $=\mathrm{Rp} .75 .000,00$ dan laba $25 \%$, yang ditanyakan harga jual barang?. Selain itu, siswa juga kesulitan dalam menentukan rumus, sehingga siswa tidak menuliskan rumus pada jawabannya. Seharusnya rumus yang digunakan adalah harga jual $=$ harga beli + untung. Sedangkan pada aspek terapan, siswa tidak mengalami kesulitan pada saat melakukan perhitungan, tetapi siswa tidak menarik kesimpulan dari jawaban soal tersebut. Seharusnya siswa menuliskan kesimpulannya, misalnya: jadi harga jual barang tersebut sebesar Rp. 56.000,00.

Permasalahan soal nomor 3:

Seorang siswa menabung di bank sebesar Rp. 100.000,00 dengan bunnga 12\% per-bulan. Setelah 7 bulan tabungan itu diambil. Berdasarkan permasalahan tersebut:

(a) buatlah tabelnya

(b) hitunglah jumlah tabungan selama 7 bulan.

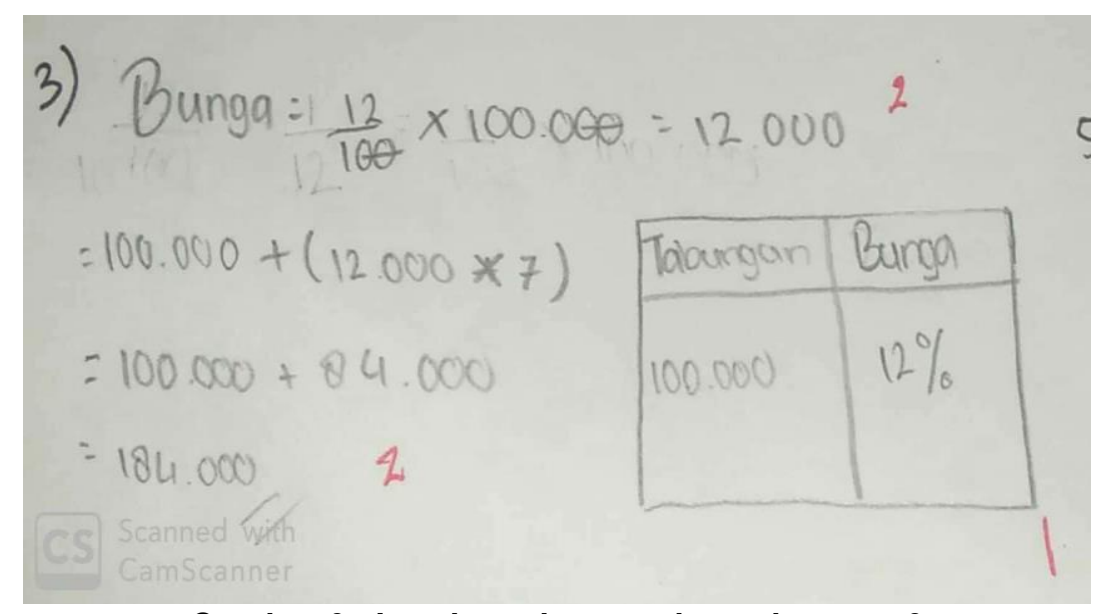

Gambar 3. Jawaban siswa pada soal nomor 3

Berdasarkan jawaban siswa pada Gambar 3, terlihat bahwa siswa mengalami kesulitan pada aspek bahasa, aspek prasyarat, dan aspek terapan. Pada aspek bahasa, siswa kesulitan dalam menafsirkan soal dengan bahasanya sendiri. Seharusnya siswa menceritakan kembali dengan bahasanya sendiri, misalnya; bunga dalam setahun dan jumlah tabungan selama 7 bulan. Selanjutnya aspek prasyarat, jawaban siswa sudah benar bahwa soal tersebut menggunakan konsep bunga tahunan, sehingga siswa tidak dianggap kesulitan pada aspek ini. Kemudian aspek terapan, siswa dalam melakukan perhitungan sudah benar tetapi belum bisa menarik kesimpulannya dari jawaban soal tersebut. Seharusnya siswa menuliskan kesimpulannya, misalnya: jadi, jumlah tabungan siswa tersebut selama 7 bulan sebesar Rp. 184.000,00.

Permasalahan soal nomor 4:

Seorang karyawan setiap bulan menerima gaji sebesar Rp. 1.300.000,00. Jika ia harus membayar pajak sebesar $5 \%$ dari gaji pokok. Apakah benar gaji bersih yang diterima karyawan itu adalah sebesar Rp. 1.235.000,00? 


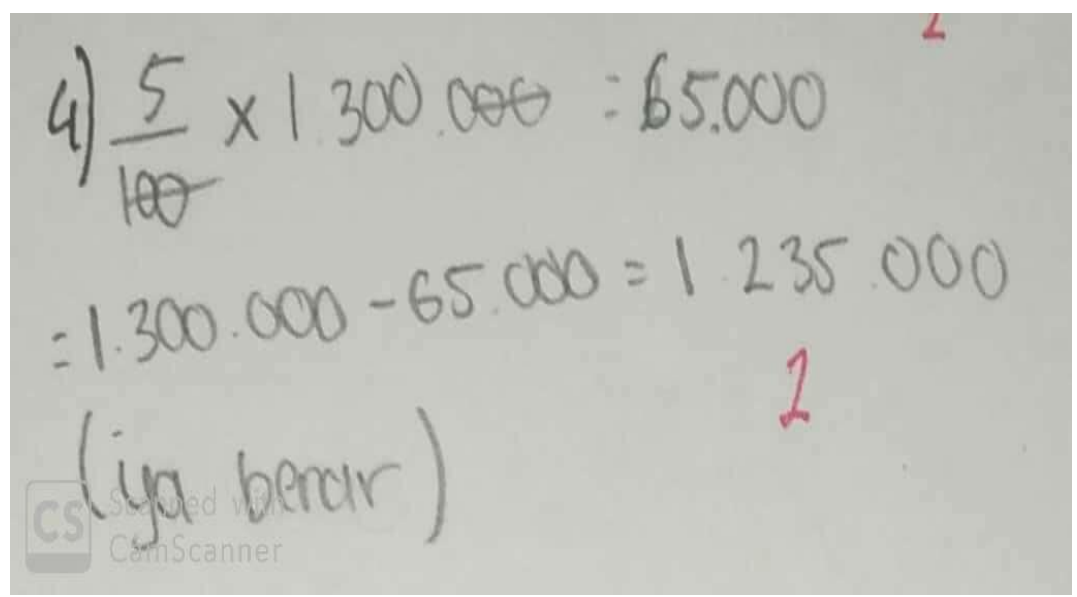

Gambar 4. Jawaban siswa pada soal nomor 4

Berdasarkan Gambar 4 diketahui bahwa kesulitan siswa dalam menyelesaikan soal diidentifikasi berasal dari tiga aspek, yaitu aspek bahasa, aspek prasyarat, dan aspek terapan. Pada aspek bahasa, siswa sulit memahami dan menafsirkan soal ke dalam bahasanya sendiri, sehingga apa yang siswa tulis hanya implementasi soal ke dalam rumus dan hasil perhitungannya. Seharusnya siswa menuliskan apa yang akan dicari sesuai dengan pertanyaan, misalnya: besar pajak penghasilan dan gaji yang diterima. Selanjutnya aspek prasyarat, jawaban pada Gambar 4 terlihat bahwa siswa mengalami kesulitan pada aspek prasyarat, secara konsep pada jawaban siswa tersebut sudah benar, tetapi siswa belum dapat menuliskan rumus yang digunakannya mungkin karena siswa tersebut lupa atau terburu-buru dalam mengerjakannya. Seharusnya kalau sudah tahu konsep pasti dapat menentukan rumus. Rumus yang digunakan yaitu: besar pajak = persen pajak $\mathrm{x}$ gaji kotor dan untuk mencari gaji bersih, gaji bersih = gaji kotor - besar pajak. Sedangkan pada aspek terapan, siswa dalam melakukan proses perhitungan sudah benar sehingga dapat dikatakan siswa tidak megalami kesulitan tetapi siswa mengalami kesulitan pada saat menarik kesimpulan mungkin karena lupa atau siswa terbiasa tidak menarik kesimpulan pada saat menjawab soal. Seharusnya siswa menarik kesimpulan, misalnya: jadi, benar gaji bersih yang diterima karyawan tersebut sebesar Rp. 1.235.000,00.

Permasalahan soal nomor 5:

Pak Romi membeli radio dengan harga sesudah diskon 15\% adalah Rp. 765.000,00. Berapakah harga radio sebelum diskon?

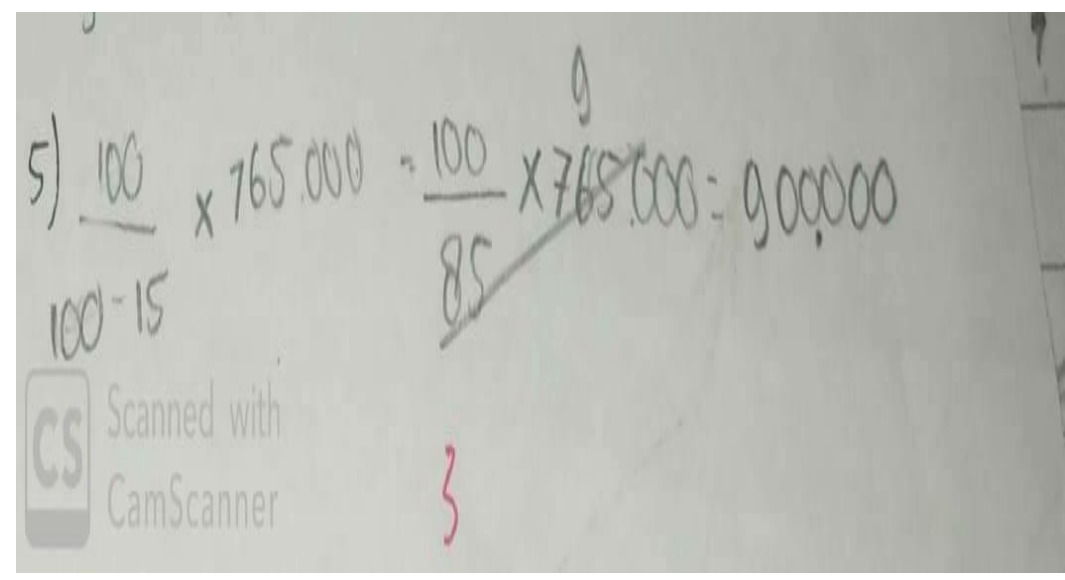

\section{Gambar 5. Jawaban siswa pada soal nomor 5}

Jawaban siswa pada Gambar 5, menunjukkan bahwa siswa mengalami kesulitan pada aspek bahasa, aspek prasyarat, dan aspek terapan. Pada aspek bahasa, siswa tidak dapat menafsirkan soal kedalam bahasanya sendiri, seharusnya siswa menuliskan harga beli barang. Kemudian pada aspek prasyarat, siswa tidak mengalami kesulitan pada konsep yang digunakan 
yaitu tentang diskon atau potongan harga, tetapi siswa mengalami kesulitan dalam menentukan rumus yang akan digunakan. Seharusnya rumus yang digunakan yaitu harga bersih = harga beli diskon. Sedangkan pada aspek terapan, siswa kesulitan dalam mengimplementasi soal ke dalam rumus tersebut, sehingga siswa sulit melakukan perhitungan. Jawaban siswa tersebut seharusnya $85 \%$. Selain itu siswa juga mengalami kesulitan dalam menarik kesimpulan karena salah dalam melakukan proses perhitungan sehingga jawaban siswa tersebut salah dan siswa tidak menarik kesimpulannya.

Adapun penyebab kesulitan yang dialami siswa, berdasarkan observasi yang dilakukan yaitu: siswa mengobrol atau tidak fokus pada saat pelaksanaan tes berlangsung, siswa lupa harus darimana mulainya, siswa juga lupa dengan rumus-rumus pada materi aritmatika sosial, siswa tidak memahami soal, siswa kurang teliti dalam menjawab soal, siswa meremehkan dalam langkah menarik kesimpulan.

Penelitian ini sejalan dengan Khasanah \& Sutaman (2015) menyimpulkan bahwa siswa cenderung mengalami kesulitan pada aspek bahasa, terdapat lima indikator kesalahannya yaitu, (1) siswa membaca soal kurang tepat sehingga salah menafsirkan soal; (2) siswa siswa sulit memahami bahasa yang kurang familiar; (3) siswa tidak memahami cerita; (4) siswa tidak mampu mengidentifikasi soal; dan (5) siswa tidak dapat menceritakan kembali. Kemudian pada aspek prasyarat, terdapat tiga indikator kesalahannya yaitu, (1) siswa tidak menuliskan atau yang dinyatakan dalam soal; (2) siswa tidak dapat mengubah ke bentuk model matematika; dan (3) siswa belum memahami konsep, sehingga salah dalam menentukan rumus. Selanjunya pada aspek terapan, terdapat dua indikator kesalahannya yaitu, (1) siswa tidak dapat menggunakan rumus dengan tepat, sehingga dalam menerapkan rumus terjadi kesalahan dan (2) kurang paham dengan materi prasyarat sehingga siswa tidak dapat menyelesaikan dengan tepat soal tersebut.

Sedangkan berdasarkan hasil penelitian yang dilakukan oleh peneliti, diperoleh informasi bawa kesulitan-kesulitan yang dialami siswa dapat diidentifikasi meliputi tiga aspek, yaitu aspek bahasa, aspek prasyarat, dan aspek terapan. Pada aspek bahasa, siswa mengalami kesulitan sebanyak $50 \%$, karena siswa sulit dalam memahami soal atau menafsirkan soal, sehingga tidak dapat menceritakan kembali dengan bahasa sendiri. Pada aspek prasyarat, siswa mengalami kesulitan tertinggi sebesar $75 \%$, karena tidak menuliskan yang diketahui dan ditanyakan dalam soal tersebut, siswa kurang memahami konsep, dan menentukan rumus yang akan digunakan. Terakhir pada aspek terapan, siswa mengalami kesulitan persentasenya sama dengan aspek bahasa yaitu sebesar $50 \%$, karena siswa sulit dalam melakukan perhitungan, sehingga jawaban siswa tidak tepat dan sulit untuk menarik kesimpulannya.

\section{KESIMPULAN DAN SARAN}

Berdasarkan hasil analisis dan pembahasan yang dilakukan peneliti, dapat disimpulkan bahwa secara keseluruhan siswa kesulitan pada saat menjawab soal aritmatika sosial. Kesulitan-kesulitan tersebut diidentifikasi berdasarkan tiga aspek, yaitu: (1) kesulitan siswa pada aspek bahasa sebesar $50 \%$, yaitu sulit memahami atau menafsirkan soal dan tidak dapat menceritakan kembali dengan bahasa sendiri; (2) kesulitan siswa pada aspek prasyarat sebesar 75\%, yaitu berkaitan dengan aspek bahasa sehingga siswa tidak menuliskan apa yang diketahui dan ditanyakan, kurang memahami konsep, dan menentukan rumus; dan (3) kesulitan siswa pada aspek terapan sebesar $50 \%$, yaitu kesulitan melakukan proses perhitungan sehingga siswa tidak menarik kesimpulan dari jawaban soal tersebut.

Selain kesulitan siswa dalam menyelesaikan soal aritmatika sosial, penyebab dari kesulitan itu terjadi karena siswa tidak paham dengan materi aritmatika tersebut. Dikarenakan pada saat belajar siswa tidak memperhatikan guru atau guru pada saat memberikan penjelasan pendekatan yang digunakan dikelas kurang maksimal. Oleh karena itu, penulis menyarankan: (1) bagi siswa yang mengalami kesulitan pada aspek bahasa disarankan agar lebih teliti dalam membaca soal dan pahami apa maksud soal tersebut, sehingga siswa dapat menceritakan kembali dengan bahasanya sendiri dan dapat menafsirkan soal tersebut; (2) bagi siswa yang mengalami kesulitan pada aspek 
prasyarat, jika mendapatkan soal cerita disarankan untuk menuliskan apa saja yang diketahui dan ditanyakan dari soal tersebut dan belajar untuk memahami konsep-konsep pada materi aritmatika sosial, serta menghapalkan rumus; dan (3) bagi siswa yang mengalami kesulitan pada aspek terapan disarankan untuk lebih teliti dalam menghitung dan juga menuliskan kesimpulan dari hasil jawaban tersebut.

\section{REKOMENDASI}

Berdasarkan hasil penelitian, maka peneliti memberikan rekomendasi untuk sekolah, siswa dan peneliti selanjutnya, diantaranya: (1) bagi sekolah, mungkin akan lebih baik lagi jika fasilitas pembelajaran dilengkapi dengan media pembelajaran, sehingga dapat memudahkan siswa dalam proses pembelajaran; (2) bagi siswa, diharapkan agar lebih aktif pada saat belajar dan mencoba mengerjakan tugas-tugas dan latihan soal yang diberikan oleh guru; dan (3) bagi peneliti selanjutnya, diharapkan agar melakukan penelitian lebih lanjut dan mendalam berkaitan dengan materi aritmatika sosial, sehingga hasil penelitiannya menjadi lebih baik lagi dan semoga penelitian ini bisa menjadi bahan rujukan bagi peneliti lain yang ingin melakukan penelitian sejenis.

\section{UCAPAN TERIMA KASIH}

Penulis mengucapkan banyak terimakasih kepada SMP Negeri 5 Cimahi karena bersedia menjadi tempat penelitian ini dan juga sudah memberikan arahan serta bimbingannya sehingga artikel ini dapat di buat dengan baik.

\section{DAFTAR PUSTAKA}

Andriani, D. (2017). Pembelajaran aritmatika sosial pada kelas vii menggunakan kemampuan pemahaman matematis melalui pendekatan saintifik. Tesis: IKIP Siliwangi.

Evijayanti, W., \& Khotimah, R. P. (2018). Analisis kesulitan siswa smp dalam menyelesaikan soal cerita aritmatika sosial. Prosiding Seminar Nasional Matematika dan Pendidikan Matematika (Sesiomadika), 295-302.

Fatimah, A. T. \& Zakiah, N. E. (2018). Kelancaran prosedural matematis dalam pemecahan masalah konteks pemasaran. Mathline: Jurnal Matematika dan Pendidikan Matematika, 3(2), 141150.

Fitri, N. M. A., Adirakasiwi, A. G., \& Utami, M. R. (2017). Analisis kesulitan siswa dalam menyelesaikan soal cerita matematika pada siswa smp, 3(2), 1-14.

Khasanah, U., \& Sutaman. (2015). Kesulitan menyelesaikan soal cerita matematika pada siswa smp. Artikel Publikasi, 1-13.

Laily, I. F. (2014). Hubungan kemampuan membaca pemahaman dengan kemampuan memahami soal cerita matematika sekolah dasar. Eduma: Mathematics Education Learning and Teaching, 3(1), 53-62.

Lestari, D. T., Rohaeti, E. E., \& Senjayawati, E. (2019). Analisis kesulitan belajar siswa smp kelas viii dalam menyelesaikan soal aritmatika ditinjau dari kemampuan komunikasi matematis. Journal on Education, 1(2), 440-444.

Marina, \& Suciati, I. (2019). Pengaruh pendekatan kontekstual terhadap prestasi belajar matematika aritmatika sosial siswa kelas vii smp negeri 3 kota palu. Jurnal Pendidikan dan Pembelajaran, 1(1), 44-52. 
Nuraida, I. (2017). Analisis kesalahan penyelesaian soal bangun ruang sisi lengkung siswa kelas ix smp negeri 5 kota tasikmalaya. Teorema: Teori dan Riset Matematika, 1(2), 25-30.

Raharjo, J. F., \& Sulaiman, H. (2017). Mengembangkan kemampuan pemahaman konsep matematika diskrit dan pembentukan karakter konstruktivis mahasiswa melalui pengembangan bahan ajar berbantuan aplikasi education edmodo bermodelkan progresif pace (project, activity, cooperative and exercise). Teorema: Teori dan Riset Matematika, 2(1), 47-62.

Sari, A. W. (2017). Diagnosis kesulitan belajar matematika siswa di tinjau dari kemampuan koneksi matematika siswa kelas viii smp muhammadiyah 2 kartasura tahun ajaran 2016/2017. Chemosphere, 7(1), 13-19.

Shalikhah, M. (2019). Analisis kesulitan siswa smp negeri 3 pleret pada materi aritmatika sosial. Academy of Education Journal, 10(1), 44-54.

White, A. L. (2010). Numeracy, literacy and newman's error analysis. Allan Leslie White Journal of Science and Mathematics Education in Southeast Asia, 33(2), 129-148.

Zakiah, N. E. (2017). Pembelajaran dengan pendekatan kontekstual berbasis gaya kognitif untuk meningkatkan kemampuan metakognitif siswa. Pedagogy 2(2), 11-29. 